\title{
Reflection and learning in clinical nursing education mediated by ePortfolio
}

\author{
Kirsten Nielsen ${ }^{* 1}$, Birthe D. Pedersen ${ }^{1}$, Niels H. Helms ${ }^{2}$ \\ ${ }^{1}$ Institute of Clinical Research, Faculty of Health Sciences, University of Southern Denmark, Odense, Denmark \\ ${ }^{2}$ Department for Research and Innovation, University College Sjælland, Sjælland, Denmark
}

Received: June 29, 2015

DOI: $10.5430 /$ jnep.v5n12p63
Accepted: August 23, 2015

Online Published: September 17, 2015

\begin{abstract}
This paper reports on an investigation into learning mediated by the elective elements of an electronic portfolio (ePortfolio) designed to facilitate four learning styles. The design takes a phenomenological-hermeneutic approach. The setting was Course 4, a ten-week clinical course in Basic Nursing. The participants were eleven first-year students on Course 4 randomly selected. Data were generated by participant observations, interviews and portfolio documents. The entire material was interpreted according to Ricoeur's theory of interpretation. The study showed that the elective elements of ePortfolio were mostly used by students with theorist style and used the least by students with pragmatist style. Some students can reflect without a learning tool, other students need supervision. The themes a fellow player and an opponent were deduced. The conclusion was that the elective elements work like fellow players and opponents, as they facilitate reflections on nursing practice and one's own learning processes, and they mediate learning of important nursing competency elements. The tools can promote differentiation of supervision, and allow more time to supervise students who need more support. There is potential to enable students to select among the learning tools.
\end{abstract}

Key Words: EPortfolio, Learning, Learning styles, Nursing education, Clinical education

\section{INTRODUCTION}

This study investigated learning mediated by the elective part of an electronic portfolio (ePortfolio) implemented in a clinical course within nursing education. It is part of a larger study investigating learning mediated by ePortfolio. Findings from a former study investigating use of the ePortfolio showed that the ePortfolio was used mostly at home. Using ePortfolio in the ward was more time-consuming. ePortfolio was used to reflect on practice and one's own learning process. The principal initiators were emotional involvement in clinical nursing, consciousness of learning through writing; ponder over practice, and a confident and constructive student-preceptor relationship. Inhibitors were vulnerability, a preconception that one learns only in one way, and lack of supervision about how to learn. ${ }^{[1]}$ Another study investigated learning mediated by the mandatory part of ePortfolio, which contains an individual study plan. The study reported that the mandatory part promoted consciousness of own learning and competencies in clinical nursing and raised students consciousness of nurse identity. It also provided preceptors the opportunity to differentiate their supervision for individual students and guide them to improve their learning potential. However, there were a potential to tailor the individual study plan. ${ }^{[2]}$ The ePortfolio was designed to facilitate four learning styles, as a review of the nursing curriculum recommended improvement of clinical courses and

\footnotetext{
${ }^{*}$ Correspondence: Kirsten Nielsen; Email: KIRN@ VIA.DK; Address: Institute of Clinical Research, Faculty of Health Sciences, University of Southern Denmark, Odense, Denmark.
} 
to take into account differentiation in the student body. ${ }^{[3]}$ The ePortfolio has both mandatory and elective elements. In the elective element, there are 16 learning tools. Some of them are e-learning tools, which can be used according to preferred learning style by video demonstrations, stepby-step information, supplementary texts, problem solving or tests. Others are documents with implemented guidance for different ways of learning, for example learning by a holistic or step-by-step approach. Finally, there are documents - so-called wikis - used for writing without any guide. The ePortfolio was tested in a pilot project, and $84 \%$ of the participants related that ePortfolio supported reflection on practice. Others evaluated that it could provide a modicum of support. ${ }^{[4]}$ The result raised questions surrounding the areas of nursing competency that are mediated, and whether there are learning styles that are not facilitated by the ePortfolio. Therefore, there was a basis for a qualitative study of the ePortfolio in practice.

\section{Background}

Prior research shows there are benefits in using an electronic portfolio (ePortfolio) and learning styles theories within nursing education, though their joint effectiveness has not been examined. EPortfolio improves students' reflections on practice and self-awareness. ${ }^{[5-7]}$ However, guidance for portfolio work needs to be improved, ${ }^{[6]}$ and a new review concludes that there is still a lack of evidence, whether the ePortfolio can be used as a tool to measure and demonstrate competence. ${ }^{[8]}$ There are several learning styles theories, but a range of theories from Kolb, ${ }^{[9]}$ Honey and Mumford ${ }^{[10]}$ and Meyer-Briggs ${ }^{[11]}$ used in previous research into learning styles showed rather similar results: Insight into learning style preferences promotes learning of important nursing competencies. ${ }^{[12-15]}$ However, other authors warn about lack of evidence for this claim and worry about the risk that teachers label students and thereby reduce them to stereotypical learners. ${ }^{[16-18]}$ Despite these inconsistencies, there seems to be a degree of truth in the efficacy of using learning styles theories, and further investigation is needed. ${ }^{[19]}$ There also remains a lack of knowledge of how ePortfolio mediates learning in clinical elements of nursing programmes. ${ }^{[7]}$ Therefore, to inform didactic considerations about how to improve learning in clinical courses and differentiate supervision, the aim of the study was to investigate learning mediated by the elective elements of an ePortfolio designed to facilitate four learning styles in a clinical course within nursing education.

\section{Framework}

The understanding of nursing practice to be learned and partly mediated by ePortfolio is inspired by the theory Inter- actional nursing practice of the Danish nurse and philosopher Merry Elisabeth Scheel. According to Scheel nursing practice is interactional nursing practice, which is based on three types of complementary knowledge and matching modes of action inspired by Habermas: cognitive-instrumental, aesthetic-expressive and moral-practical. ${ }^{[20]}$ In the context of interactional nursing practice the cognitive-instrumental mode of action focuses on integrating the nursing process as a result-oriented, effective mode of action to meet bodily needs, ${ }^{[20]}$ and this is a part of curriculum of Course 4. ${ }^{[21]}$ According to Scheel cognitive-instrumental knowledge is explicit theoretic knowledge combined with knowledge of practical nursing skills. ${ }^{[20]}$ Furthermore, basic nursing of the course focuses on self-reflection and understanding the individual patient situation and other professionals. ${ }^{[21]}$ This comes under the aesthetic-expressive mode of action, as in interactional nursing practice aesthetic-expressive knowledge is knowledge sensed in the patient situation interpreted with theoretical knowledge in interaction with the patient. ${ }^{[20]} \mathrm{Fi}^{-}$ nally, there is a focus in basic nursing on communication and co-operation, the ability to shape relations to other people according to ethical norms in given circumstances. ${ }^{[21]}$ This is included in the moral-practical mode of action, as according to Scheel moral-practical knowledge is a combination of ethical knowledge about how to create a relation to other people combined with knowledge of the practical situation, its possibilities and limitations. ${ }^{[20]}$

Therefore, achieving the ability to make qualified judgements is based on a combination of cognitive-instrumental, aesthetic-expressive and moral-practical knowledge and action. The three forms of knowledge are, respectively, linked to natural, human and social sciences without any sharp division.

\section{MeTHODS}

\subsection{Research design}

The design takes a phenomenological-hermeneutic approach, inspired by the ethnographer James P. Spradley's theory of participant observation ${ }^{[22]}$ and the philosopher Paul Ricoeur's theory of narratives and interpretation, ${ }^{[23,24]}$ in order to understand learning mediated by ePortfolio through qualitative description and narrative language.

\subsection{Settings and participants}

The setting was Course 4, a 10-week clinical course in basic nursing in a Danish School of Nursing. The clinical placements were at three hospitals and a nursing home, where the ePortfolio designed to facilitate four learning styles had been tested for a year. The inclusion criteria were students about to begin the course. To include students with different ways 
of learning, 40 first-year students answered a 40-question learning style indicator. ${ }^{[25]}$ The learning style indicator was inspired by the Honey and Mumford Learning Styles Questionnaire ${ }^{[26]}$ and developed for Danish conditions by the company@ventures within the Danish Knowledge Centre for e-learning. The indicator reliability was, together with Honey and Mumford's 80-question questionnaire, tested on young people (15-19 years) and adults. The indicator showed "very accurate", "accurate", or "reasonably accurate" for approximately $92 \%$ of users. ${ }^{[25]}$ It gave an indication of whether the students' preferred learning styles were activist, reflector, theorist or pragmatist style as well as an individual learning style profile. On this basis, the students were divided into four subgroups. From the groups with respectively activist, reflector, and theorist style, three students were included using a random number generator. As there were only two of the forty students, who had highest score for pragmatic style they were both included. Of the included students, two were about to change course, two wanted to change campus, and one did not want to participate. Instead, five other students were included, so in all ten female and one male student were included. The sample size was determined beforehand, as the course set a time limit for the participant observations within ten weeks. Furthermore, it was necessary to make a lot of arrangements with the Head of Nursing at the hospitals and the nursing home before following the students.

\subsection{Generation of data}

Data was generated by participant observations, narrative interviews and portfolio documents in order to highlight the learning process from different perspectives and allow for mutual support between them. ${ }^{[22]}$ Each student was followed on one of the first and one of the final days of the course. A day began with participant observations of a stu- dent practising. The observations were noted concurrently, as recommended. ${ }^{[22]}$ Following the practice, the first interview took place. Students related their experiences of caring for patients. Afterwards, the student worked with the ePortfolio for about half an hour. At the second interview, held after portfolio work, the students related their experiences by working with ePortfolio. The interviews and portfolio work took place in a quiet room at the placement. A fair copy of the field notes were written out, the interviews were recorded and transcribed, and the portfolio documents were copied. Thus, all the data material from participant observations, narrative interviews and portfolio documents were available as text.

\subsection{Ethical considerations}

Before commencing the study, the Head of Nursing at the hospitals and the nursing home approved access to the clinical placements. The students received oral and written information and were included after informed consent. During the participant observations, the patients were informed that the learning process of the students was the focus of the study. Ethical Guidelines for Nursing Research in Scandinavia, which includes the Helsinki Declaration ${ }^{[27]}$ were followed. The study was submitted to the Danish Data Agency. Formal approval from the local Scientific Ethics Committee was not required, in accordance with national legislation in Denmark.

\subsection{Interpretation}

The entire text material was interpreted using a method inspired by the French philosopher Paul Ricoeur's theory of interpretation on three levels: naive reading, structural analysis and critical interpretation and discussion. ${ }^{[23,28,29]}$ The method of analysis is illustrated in Figure 1.

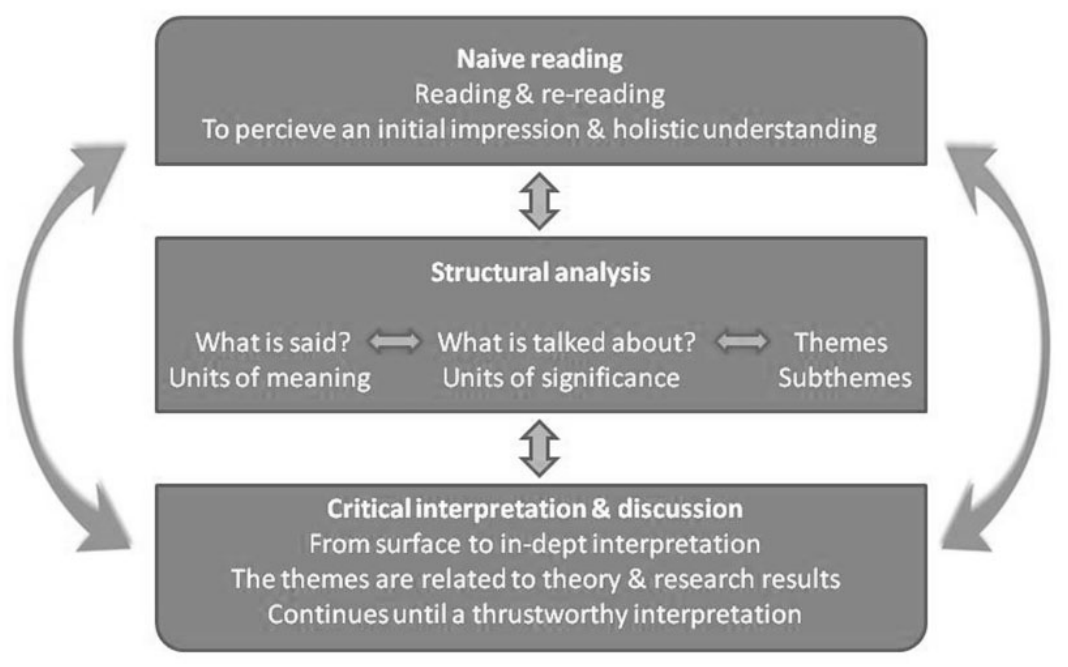

Figure 1. Illustration of the interpretation 
Naive reading is the phenomenological part of the interpretation, where we read and re-read the texts in order to reach a holistic understanding and thereby delimit the number of possible interpretations of the sentences. Structural analysis is the explanatory element, where the texts were systematised using the computer programme NVivo 9. The sentences are analysed in order to identify the units of meaning (what is said) and units of significance (what is being talked about). Themes are drawn out from the entire data material for further interpretation. Critical interpretation and discussion are based on these themes and are related to theory and other research results. The critical interpretation is a process involving a movement from the specific to the general. The interpretation was carried out in cooperation within the research group and moved backwards and forwards between the levels in a hermeneutic helix until we reached strengthened arguments for a trustworthy interpretation. In the following paragraphs the abbreviations in parentheses after the quotations refer to participant observations $(\mathrm{O})$, narrative interviews (I), or portfolio documents (D). The numbers refer to individual participant number, and the last letters refer to preferred learning style: Activist style (A), Reflector style $(\mathrm{R})$, Theorist style (T), and Pragmatist style (P).

\section{Findings}

At first, in order to get an overview of the content in the elective elements of the ePortfolios, portfolio documents were collated in Table 1. Then the themes that appeared during the naive reading and the structural analysis will be interpreted and illustrated with quotations. The themes were: the elective elements as a fellow player and as an opponent.

\subsection{Content in the elective elements}

The analysis of portfolio content showed how students with different learning styles used the elective elements of ePortfolio both with and without learning tools (see Table 1). Of the 16 learning tools available, it was only use of the six listed in Table 1, which were documented in the elective elements. Two students (D: 6R, 10P) always used learning tools when writing in the ePortfolio, while five students (D: 2A, 4R, 7T, 9T, 11P) sometimes and four students (D: 1A, $3 \mathrm{~A}, 5 \mathrm{R}, 8 \mathrm{~T}$ ) seldom used learning tools. Learning tools were used in 55 documents, and not used in 92 documents. The students each used from two to four different learning tools. Employment of a single tool varied from one to seventeen times. The extent of written feedback from preceptors varied from none feedback to feedback in every document.

Table 1. Content in the elective elements of ePortfolio

\begin{tabular}{|c|c|c|c|c|c|c|c|c|c|}
\hline \multirow[b]{2}{*}{ Students } & \multirow[t]{2}{*}{$\begin{array}{l}\text { Portfolio documents } \\
\text { without learning } \\
\text { tools }\end{array}$} & \multicolumn{6}{|c|}{ Portfolio documents with learning tools } & \multirow[t]{2}{*}{$\begin{array}{l}\text { In } \\
\text { all }\end{array}$} & \multirow[t]{2}{*}{$\begin{array}{l}\text { Feed } \\
\text { back from } \\
\text { preceptor }\end{array}$} \\
\hline & & $\begin{array}{l}\text { Nursing } \\
\text { process }\end{array}$ & $\begin{array}{l}\text { Reflection } \\
\text { process }\end{array}$ & $\begin{array}{l}\text { Patient } \\
\text { pathway }\end{array}$ & $\begin{array}{l}\text { Clinical } \\
\text { rating scale }\end{array}$ & $\begin{array}{l}\text { Clinical } \\
\text { skills }\end{array}$ & $\begin{array}{l}\text { Reflection } \\
\text { on learning } \\
\text { outcome }\end{array}$ & & \\
\hline $1 \mathrm{~A}$ & 11 & & & 1 & & 1 & & 13 & 12 \\
\hline $2 \mathrm{~A}$ & 9 & & 1 & & 1 & 1 & 2 & 14 & 7 \\
\hline $3 \mathrm{~A}$ & 18 & & & & & 1 & 1 & 20 & 14 \\
\hline $4 \mathrm{R}$ & 2 & & & & & 1 & 4 & 7 & 7 \\
\hline $5 \mathrm{R}$ & 12 & & & & & 1 & 1 & 14 & 6 \\
\hline $6 \mathrm{R}$ & 0 & & & 1 & 1 & 1 & 17 & 20 & 5 \\
\hline $7 \mathrm{~T}$ & 17 & 2 & & & & 1 & 3 & 23 & 3 \\
\hline $8 \mathrm{~T}$ & 15 & & & & 1 & & 2 & 18 & 1 \\
\hline $9 \mathrm{~T}$ & 7 & & & & & 1 & 3 & 11 & 3 \\
\hline $10 \mathrm{P}$ & 0 & & & 1 & & 1 & 1 & 3 & 0 \\
\hline $11 \mathrm{P}$ & 1 & & & & & 1 & 2 & 4 & 1 \\
\hline In all & 92 & 2 & 1 & 3 & 3 & 10 & 36 & 147 & \\
\hline
\end{tabular}

Table 1 shows that students with pragmatist as preferred learning style used the elective elements sparingly; however, they did use learning tools. They got very little or no written feedback. Students with the other preferred learning styles used the elective elements a lot more. Students with activist and reflector styles got most written feedback. Except in one case (O6R), examination of the field notes showed little oral feedback on work with elective elements. Thus, written and oral feedback seems to be a significant factor for using the elective elements, apart from students with theorist style, who used the elective elements the most, even though they got little feedback. 


\subsection{A fellow player}

The analysis showed how students with different preferred learning styles used the elective elements to reflect about practice; thus, the ePortfolio worked like a fellow player. One student wrote: "I observed that the skin around the peripheral intravenous catheter (PVC) was wet, the drip didn't run. . . the PVC was removed... it was difficult to stop the bleeding as he had anticoagulant therapy... I elevated the arm and compressed..." (D3A). "The patient had diarrhoea... think the reason is enteral feeds through a nasogastric tube..." (D8T). These quotations showed how some students applied theoretical knowledge in reflections on practice without the help of a learning tool. Just writing about experiences promoted reflection. Others used learning tools: "We used it for reflection on patient assessment, nursing diagnosis, and goal setting" (I7T). The quotation is about using the Nursing process elearning tool to reflect in co-operation with other students and their preceptor. According to the quotation, it seems as if it was used step-by-step. Subsequently, the student used it twice independently (see Table 1). Using the e-learning tool for joint reflection seemed to initiate writing step-by-step about assessment, diagnosis and goal-setting in ePortfolio, as is characteristic of the theorist style.

The following quotation is about using the Reflection process tool: "I was changing an analgesic plaster. . I observed her skin for reactions. .. she had showered, but I considered if I should have cleansed the skin even so, as it was my responsibility. . . next time I will cleanse the skin carefully..." (D2A). As is characteristic of the activist style, this student acted first and was afterwards guided to clinical judgement by the learning tool. A quotation from a document using the Patient pathway tool states: "The patient had back pain and was wheel-chaired... nurse and physiotherapist cooperated with (the patient)... but pushed her to get out of the wheelchair and walk... now she seems more satisfied... and moves without pain... (The relation) motivated her to come home to her child again... I learned that being tolerant and positive in relation to the patient is worthwhile" (D10P). Afterwards the student related: "You get the whole picture" (I10P). The tool's clear connection between subject to be learned and practice seemed to fit the pragmatist style. It made clear the effect of a tolerant and positive attitude on the patient's pathway.

These quotations show that the Nursing process, Reflection process and Patient pathway tools primarily guide reflections on practice and to a certain extent reflections on learning. The analysis points somewhat towards a potential benefit of using a learning tool suitable for the learning style, as students are guided to make clinical judgements. In this way, the ePortfolio can be seen as a fellow player.

\subsection{An opponent}

When focus was on the learning process, the analysis showed how, the ePortfolio worked like an opponent. One student wrote without learning tools: "Today I managed to use the handicap lift by myself. That made me very proud" (D5R) The sole act of writing made her success explicit to the preceptor, who was not present. The following quotations are from using the Clinical rating scale tool. "I am able to take initiative to carry out tasks... compared to the rating scale I am between assisted and supervised level. I don't need much supervision, but I need to practise judging what is essential and not essential in a situation" (D2A). This self-evaluation made the student identify a learning need and consider her own position in relation to competent nursing practice. The next quotation was from the participant observation: "The student assesses herself being partly on the marginal and partly the assisted level. The preceptor agrees" (O10P). In this case a student is evaluating her own competencies in cooperation with the preceptor. The quotations illustrate how some students evaluate themselves independently, guided by the Clinical rating scale, while others prefer to receive support from the preceptor. Most students completed the tool Clinical skills and related: "I update the document continuously" (I: 3A, 4R, 8T, 9T), "[The preceptor] can see what I have practised, so she doesn't need to ask..." (I5R). This tool provided a general overview of learned clinical skills and skills to be learned for both students and preceptors. The quotations show that Clinical rating scale and Clinical skills primarily facilitate evaluation and reflection on the learning process. Additionally, when students and preceptors share the rating scale, this promotes understanding and consciousness of learning level assessment.

The following is from using the Reflection on learning outcome tool: "To be able to... identify phenomena related to physiological needs and reactions on illness, disease and suffering (I will) reflect on practice and practise observing the patients. This morning, Mrs. X's oxygen tube was placed incorrectly...blood oxygen saturation was $88 \%$. She was different from yesterday, tired, didn't open her eyes, and didn't answer much. I placed the tube correctly... After an hour the saturation was $91 \%$, and she was awake and smiling... Hypoxemia in the cells leads to cyanosis, tiredness... decrease in consciousness... When she is tired she needs to rest more and probably cannot manage much talking... Am able to judge essential from not essential in the situation (I will) continue practising... nursing competencies" (D4R). About the tool, students related: "One can use it to remember all aspects [of nursing] that you don't think of without it" (I7T); "You delve deeply theoretically... to achieve a learning outcome" (I8T). Both reflections on prac- 
tice and learning were facilitated, as the writings involved practical, ethical, and theoretical reflections on nursing practice, as well as actions necessary to achieve and evaluate a certain learning outcome. Thereby, it also promoted consideration of one's own position in relation to competent nursing practice. Thus, the learning tools work like fellow players and opponents.

Other quotations illustrated the difference a learning tool can mediate. One student wrote without a learning tool: "I was measuring temperature, pulse and blood pressure. I met an outpatient, who arrived for medical examination. I assisted a lady to gather the things she needed for personal cleansing..." (D7T). This quotation described what happened and helped in remembering the situation. After supervision, to use learning tools she wrote: "When the patient did not smoke and had no bronchodilators prior to the test, the result was most valid... the patient inhales as deeply as possible... the expiration is especially difficult, this creates too high a pressure in the alveoli... I will inform the patient before the test... to avoid him getting confused..." (D7T). The tool guided the student to make practical, theoretical and ethical considerations and documented track of learning about relevant knowledge and one's own position in relation to competent nursing. In this way, the ePortfolio worked like an opponent.

Few students are capable of choosing a suitable tool independently. Most students expressed a need for follow-up guidance. Only two students (I: 1A, 3A) with activist style did not ask for supervision to choose a tool. They seldom used tools but got a lot of written feedback from their preceptors. Thus, there are reasons for intensifying supervision about choice of learning tools to exploit the learning possibilities they provide. The different perspectives of the tools can facilitate differentiation of supervision, as any writing makes explicit the experience and how it was understood. Reading the text provides an impression of learning outcome and learning needs, which can promote ideas to facilitate further learning. Thus, it is not a question of choosing one learning tool for one learning style. In order to broaden learning possibilities, different learning tools are applicable, depending on learning needs, and preferred and potential learning styles. Since some students can use the tools independently, there is more time to supervise students who need the most support. Thus, there are benefits, not only to students but also to preceptors and for the improvement of clinical practice.

\section{Discussion}

The study showed that the elective elements and, in particular, the learning tools worked like fellow players and opponents, as they facilitated reflections on nursing practice and one's own learning process. According to Scheel, nursing competencies are achieved by experience from participation in many nuanced learning processes in practice, acquired theoretical knowledge and valid ethical norms. ${ }^{[30]}$ Writing in the elective elements about a range of practice situations can then nuance the concept and meaning of nursing, and writing fixes the experience, both in the documentation and in one's consciousness. Writing mediated reflections on practical, theoretical and ethical knowledge. Those types of knowledge correlate with cognitive-instrumental, aestheticexpressive and moral-practical knowledge, and reflections on different types of knowledge contributed to the formation of ethical conduct. Thus, the elective elements mediated important elements of nursing competency. However, the correlation between reflection and learning and the quality of written reflections must be developed further. According to Hermansen, ${ }^{[31]}$ who is in line with Schön, reflections are necessary when something demands a conscious decision, or when something already learned has to be transformed and learned again. Hermansen approaches learning on two levels. Learning on level one is an integrated and tacit process of automatic learning. Learning on level two involves explicit reflections on the learning process and how to learn or on solving problems in practice, when the intuitive approach is ineffective. ${ }^{[31]}$ As the quotations from portfolio documents are explicit and interpreted to be reflections on nursing practice and the learning process, including how to learn, it indicates that the written reflections are learning on level two. According to Scheel, self-reflection and reflection on, and interpretation of, various nursing situations are crucial activities in order to make qualified judgements. ${ }^{[30]}$ This indicates that reflection on, and evaluation of, one's own learning process as well as reflection on practice in ePortfolio contribute to learning nursing competencies.

There is, however, potential to exploit the learning possibilities of the tools further, as most portfolio documents are writings without the use of learning tools and some of these writings could have been more reflective using a tools' guide. A study within healthcare showed that ePortfolio with integrated instructions, such as tutorials and examples, provided distinct support for students enrolled in a master degree programme. The tools were appreciated and reduced the need for instructor support. ${ }^{[32]}$ The findings could be due to the higher level of education and that students who choose an on-line course are prepared for more self-directed learning. A literature review about post-registration learners' use of technology-enabled tools in self-directed learning found that some studies showed improved learning, while others did not. The study recommended that the design of learning tools take into account individual learning styles. ${ }^{[33]}$ The learning tools 
in our study were designed to take into account different learning styles, and still some used them sparingly. However, according to Scheel, learning to use technology is also necessary to solve specific nursing tasks. ${ }^{[30]}$ So, ICT competence needs to be supported. A study of newly enrolled nursing students' attitudes to ICT showed that, institutions of higher education cannot take for granted that students have adequate ICT competencies. ${ }^{[34]}$ Prior ICT competencies can partly, but not fully, explain why a third of the students in our study seldom used the learning tools, as two of these students had a prior education where ICT skills were highly weighted. Neither does it explain why students with pragmatist style use the elective elements of ePortfolio sparingly. According to Honey and Mumford, pragmatist style indicates a preference to learning when there is a clear connection between what has to be learned and practice, when they get instructions from a skilled person, and when they can make plans with clear goals. ${ }^{[35]}$ One reason could be that it seemed unclear to these students how writing in the elective elements facilitated learning clinical nursing. Besides, use of the elements was elective, not mandatory, and they received almost no written feedback on their work. According to Scheel, nursing competencies in practice are learned in close interaction with a preceptor as the trial-and-error method will involve a risk to the patient. ${ }^{[30]}$ Some interactions could take place in ePortfolio, as some writings were unexploited learning possibilities. The study showed that most students needed guidance to select a learning tool, and former studies also found that guidance and feedback was important for portfolios to be successful, ${ }^{[8,36]}$ especially in the early stages of portfolio use. ${ }^{[7]}$ This concurs with our study, as the participants were first-year students. However, students with theorist style use the elective elements the most and without much feedback. According to Honey and Mumford, theorist style shows by preference to learn by making methodically investigations of coherence between concepts, events and situations, by asking questions, analysing, and working independently. ${ }^{[35]}$ This is possible using the elective elements, and perhaps the explanation is that, if they get supervision at the beginning of the course, they are subsequently able to use the elements independently.

\section{Conclusion}

The elective elements and especially the learning tools designed to fit different learning styles work like fellow players and opponents, as they facilitate reflections on nursing practice and one's own learning processes. The elements mediated a nuanced concept of nursing, complementary types of knowledge and ethical conduct - important elements of nursing competency. They also mediated consciousness about one's own learning process and how to learn. The tools can promote differentiation of supervision, and allow more time to supervise students who need more support. There is a potential to enable students to select among the learning tools, so the learning possibilities they provide can be better utilised.

\subsection{Implications for nursing education}

Thus implications for nursing education are to emphasize making nursing students with different preferred learning styles understand two essentials: First that the ePortfolio provides a possibility to learn about nursing through writing in the elective elements about various practice situations, as this process can nuance the concept and meaning of nursing for students. Second that reflection on nursing practice and one's own learning process makes explicit to the preceptor and oneself what is already learned and what still has to be learned. This provides an opportunity to learn more about nursing, as the preceptor will be able to differentiate guidance to the learning need of the single student - and the student will be able to ask for guidance or investigate a learning need independently.

\subsection{Limitations and directions for future research}

Limitations of this study are that it only included first-year students from Course 4, and that is was only carried out in one School of Nursing. Therefore, suggestions for future research could be to carry out a study of learning styles and learning mediated by ePortfolio including first-year, secondyear, and third-year students in order to gain knowledge about how both students and preceptors benefit from ePortfolio and knowing about learning styles throughout the nursing education. As well as to include a number of schools of nursing or other undergraduate programmes at other institutions in a future study investigating learning mediated by ePortfolio in combination with learning styles.

\section{CONFlicts OF InTEREST Disclosure}

The authors declare that they have no conflict of interests.

\section{REFERENCES}

[1] Nielsen K, Pedersen BD, Helms NH. Eportfolio and learning styles in clinical nursing education. Journal of Nursing Education and Practice.
2015; 5(9): 54-62.http://dx.doi.org/10.5430/jnep.v5n9p5

[2] Nielsen K, Pedersen BD, Helms NH. Becoming conscious of learn- 
ing and nursing in clinical settings. The International Journal for Recording Achievement, Planning and Portfolios. 2015; 1(1): 11-9.

[3] Ministry of Education. Anbefalinger til en revision af sygeplejerskeuddannelsen. [Recommendations for a revision of the Nursing Education]. Ministry of Education. 2008. Available from: http://www. sygeplejerskeuddannelsen.dk/Toplinks/0 m-os/Arkiv/ /media/Files/Dok/Anbefalinger_0181030 21. ashxDanish

[4] Nielsen K, Kjeldsen LPB. Når e-portfolio bygger bro mellem teori og praksis [Eportfolio are building a bridge between theory and practice] VIA University College: Development Department. 2009. Available from: https://www.ucviden.dk/portal-via/da/publicat ions/naar-eportfolio-bygger-bro-mellem-teori-og-p raksis (8802e24f-eae8-46e9-a6d4-fe0fe0a90dcd).html

[5] Jones JM, Sackett K, Erdley WS, et al. Chapter 13: ePortfolios in nursing education: Not your mother's resume. ANNU REV NURS EDUC. 2007; 5: 245-58.

[6] McMullan M. Using portfolios for clinical practice learning and assessment: The pre-registration nursing student's perspective. Nurse Educ Today. 2008; 28(7): 873-9. PMid:18180078 http://dx.doi . org $/ 10.1016 / j$.nedt .2007 .11 .006

[7] Buckley S, Coleman J, Davison I, et al. The educational effects of portfolios on undergraduate student learning: A best evidence medical education (BEME) systematic review. Medical teacher. 2009; 31(4): 340-55. PMid:19404891 http://dx.doi .org/10 .1080/0 1421590902889897

[8] Green J, Wyllie A, Jackson D. Electronic portfolios in nursing education: A review of the litterature. NURSE EDUC PRACT. 2014; 14(1): 4-8. PMid:24090523 http://dx.doi.org/10.1016/j.n epr.2013.08.011

[9] Kolb DA. Experiental Learning. Experience as the source of learning and development. Upper Saddle River, New Jersey: Prentice Hall, Inc.; 1984.

[10] Honey P, Mumford A. The manual of Learning Styles. London: Peter Honey; 1992.

[11] Desmedt E, Valcke M. Mapping the learning styles "jungle": An overview of the literature based om citation analysis. Educational Psychology. 2004; 24(4): 445-64. http://dx.doi .org/10.1080 10144341042000228843

[12] Rassool GH, Rawaf S. Learning style preferences of undergraduate nursing students. Nurs Stand. 2007 Apr; 21(32): 35-41. PMid:17479786 http://dx.doi.org/10.7748/ns2007.04.21. 32.35.c4495

[13] An GJ, Yoo MS. Critical thinking and learning styles of nursing students at the baccalaureate nursing program in korea. Contemporary Nurse. 2008; 29(1): 100-9. http://dx.doi.org/10.5172/conu . 673.29 .1 .100

[14] Li YS, Chen PS, Tsai SJ. A comparison of the learning styles among different nursing programs in taiwan: Implications for nursing education. Nurse Educ Today. 2008 Jan; 28(1): 70-6. PMid:17391813 http://dx.doi.org/10.1016/j.nedt.2007.02.007

[15] Fleming S, Mckee G, Huntley-Moore S. Undergraduate nursing students' learning styles: A longitudinal study. Nurse Educ Today. 2011 31(5): 444-9. PMid:20863600 http://dx.doi.org/10.1016/j .nedt.2010.08.005

[16] Cassidy S. Learning styles: An overview of theories, models, and measures. Educational Psychology. 2004; 24(4): 419-44. http: //dx.doi.org/10.1080/0144341042000228834

[17] Coffield F, Moseley D, Hall E, et al. Should we be using learning styles? What research has to say to practice? London: Learning and Skills Research Centre; 2004. Available from: http://www. lsda .org.uk/files/pdf/1540.pdf
[18] Pashler H, McDaniel M, Rohrer D, et al. Learning styles concepts and evidence. Psychological science in the public interest. 2008; 9(3): 105-19. PMid:26162104

[19] DeYoung S. Teaching strategies for nurse educators. 2nd ed. Upper Saddle River, N.J.: Prentice Hall; 2009. 300p.

[20] Scheel ME, Pedersen BD, Rosenkrands V. Interactional nursing a practice-theory in the dynamic field between the natural, human and social sciences. Scand J Caring Sci. 2008; 22(4): 62936. PMid:19068053 http://dx.doi.org/10.1111/j.1471-6 712.2007.00564. $\mathrm{x}$

[21] School of Nursing Campus Holstebro. Modulbeskrivelse Modul 4 [Curriculum course 4]. 2012. Available from: http://www.viauc.dk/sygeplejerske/Documents/Udd annelsesdokumenter/SFH-Modul\%204.pdf

[22] Spradley JP. Participant observation. South Melbourne: Wadsworth, Cengage Learning; 1980. 195p.

[23] Ricoeur P. Interpretation theory: Discourse and the surplus of meaning. TCU Press; 1976.

[24] Ricoeur P. From text to action. Evanston, Ill.: Northwestern University Press; 1991. 346p.

[25] Ventures. Find din læringsstil [Know your learning style]. 2014. Available from: http://www. ventures.dk/laeringsstil/vok sne.htm

[26] Honey P, Mumford A. The Learning Styles Questionaire: 80-item version. Peter Honey Publications Ltd.; 2000.

[27] Northern Nurses' Federation. Ethical Guidelines for Nursing Research in the Nordic Countries. Available from: http://old.sykepleien.no/ikbViewer/Content/3378 89/SSNs\%20etiske\%20retningslinjer.pdf

[28] Pedersen BD. Sygeplejepraksis: sprog \& erkendelse [Nursing practice. Lauguage \& Cognition]. Aarhus: Det Sundhedsvidenskabelige Fakultet, Aarhus Universitet og Danmarks Sygeplejerskehøjskole ved Aarhus Universitet; 1999. 241p.

[29] Lindseth A, Norberg A. A phenomenological hermeneutical method for researching lived experience. Scand J Caring Sci. 2004; 18(2): 145-53. PMid:15147477 http://dx.doi.org/10.1111/j.147 1-6712.2004.00258.x

[30] Scheel ME. Interaktionel sygeplejepraksis [Interactional Nursing]. 3rd ed. Copenhagen: Munksgaard Danmark; 2005.

[31] Hermansen M. Omlæring [Relearning]. 1st ed. Århus: Klim; 2003. $190 \mathrm{p}$.

[32] Shepherd CE, Bolliger DU. The effects of electronic portfolio tools on online students' perceived support and cognitive load. The Internet and Higher Education. 2011; 14(3): 142-9. http://dx.doi.org/1 $0.1016 / j$. iheduc. 2011.01.002

[33] Petty J. Interactive, technology-enhanced self-regulated learning tools in healthcare education: A literature review. Nurse Education Today. 2013; 33(1): 53-59. PMid:22818225 http://dx.doi .org/10.10 $16 / j$.nedt. 2012.06.008

[34] Kolbæk R. Holdninger til brugen af it i teoretisk uddannelse og klinisk sygepleje hos nystartede sygeplejestuderende [Newly enrolled nursing students' attitudes to ICT within education and clinical practice]. København: Københavns Universitet, Det Humanistiske Fakultet, Center for Kønsforskning; 2012. 263p.

[35] Honey P, Mumford A. Lärstilar. Handledarguide [The learning Styles Helper's Guide]. Paulsson E, translator; Studentlitteratur; 2000.

[36] McMullan M. Using portfolios for clinical practice learning and assessment: The pre-registration nursing student's perspective. Nurse Educ Today. 2008; 28(7): 873-9. PMid:18180078 http://dx.doi . org $/ 10.1016 / j$. nedt .2007 .11 .006 